\title{
TNFSF18 wt Allele
}

National Cancer Institute

\section{Source}

National Cancer Institute. TNFSF18 wt Allele. NCI Thesaurus. Code C143027.

Human TNFSF18 wild-type allele is located in the vicinity of 1q25.1 and is approximately

$11 \mathrm{~kb}$ in leng th. This allele, which encodes tumor necrosis factor ligand superfamily

member 18 protein, is involved in the positive regulation of T-cell survival. 